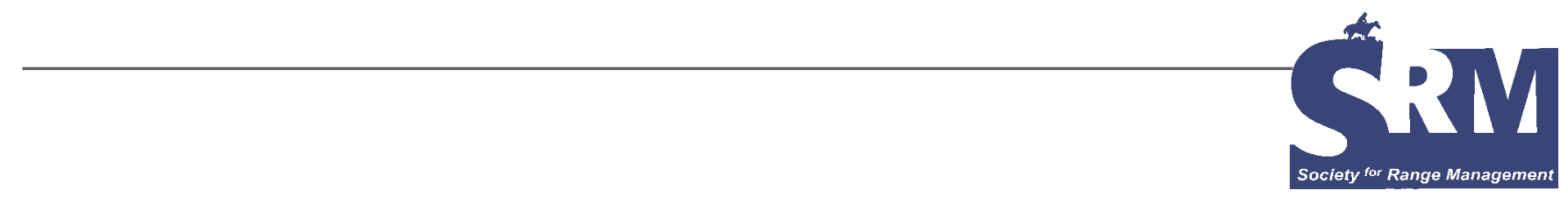

\title{
Cheatgrass and Grazing Rangelands
}

\section{By James A. Young and Charlie D. Clements}

\begin{abstract}
The presence of annual grasses creates a controversy between livestock men and grazing administrators involving the following question: Do annual grasses indicate overgrazing? Would the annual grasses be largely absent from Nevada ranges if there had been no grazing? Should the carrying capacity of a range predominantly annual be based upon the perennials? Has anyone a practical method by which annuals can be replaced and perennials reestablished in a density which would permit saying that the range had been brought back to its pioneer carrying capacity? Is it reasonable to look at a range and if annuals predominate say the range is overstocked and a reduction in livestock numbers should be made ?... And if the answers are largely negative, will we not then have to live with the annuals and learn to make the most profitable use of them?
\end{abstract}

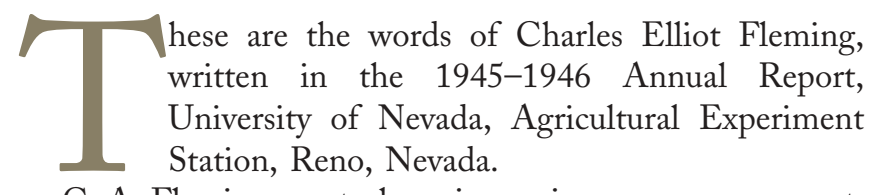

C. A. Fleming was truly a pioneer in range management. He was born in Ogden, Utah, in 1889. He graduated from Utah State Agricultural College in 1909. In 1910 he received a BSA from Cornell University in Ithaca, New York, and the same year was employed by the US Department of Agriculture, Forest Service, but spent the winter of 1910-1911 studying botany and ecology at the University of Minnesota. He served as a Grazing Examiner for the Forest Service, and then served as a researcher at both the Jornada Grazing Reserve in New Mexico and the Santa Rita Grazing Reserve in Arizona. Fleming joined the staff of the Nevada

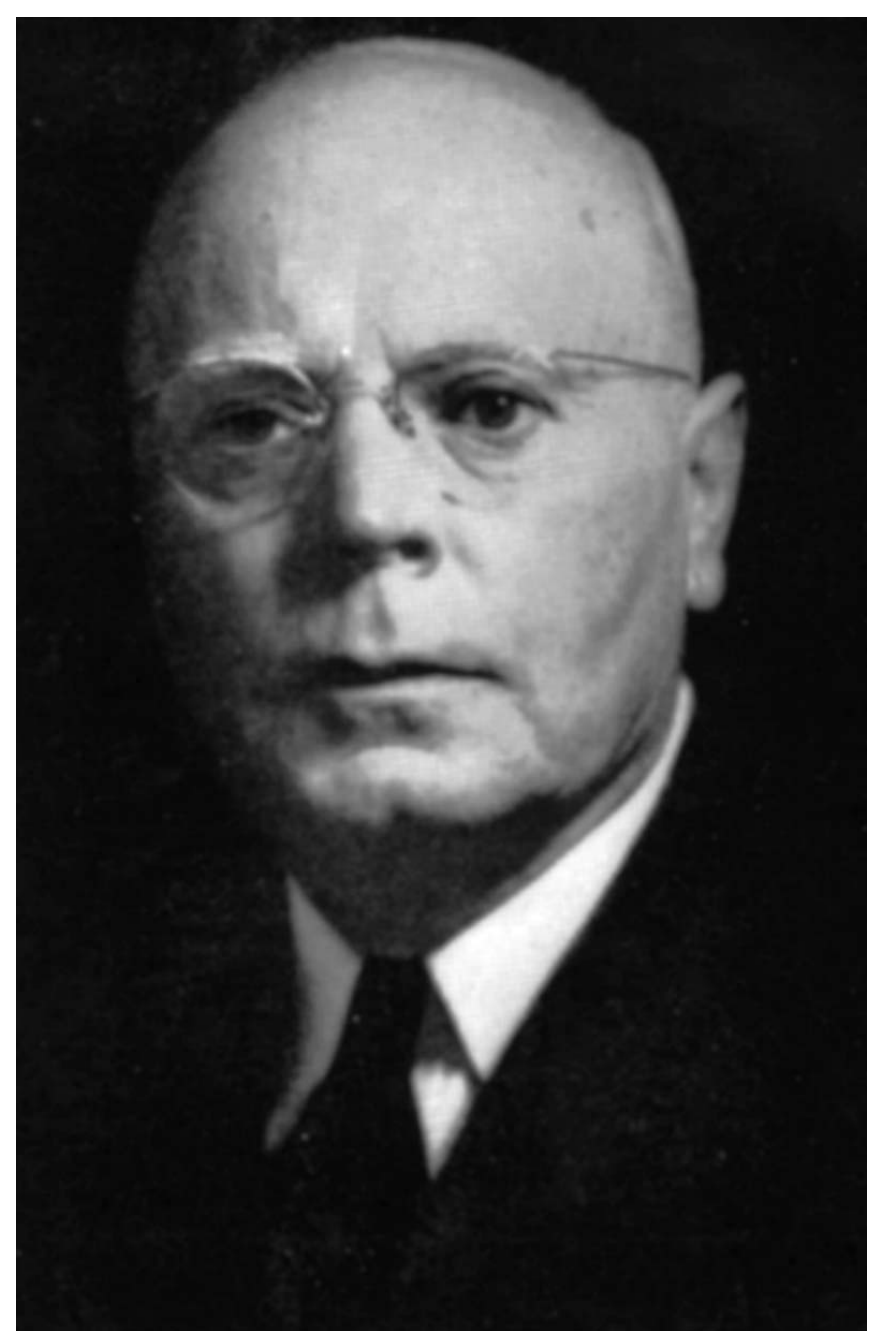


Agricultural Experiment Station as Chief of the Department of Range Management in 1916. He became Director of the Experiment Station in 1946.

Fleming, almost immediately after his appointment to the Nevada Agricultural Experiment Station, gained notoriety in range management with the publication of his Bulletin 94, "One-Night Camps vs Established BedGrounds of Nevada Sheep Ranges." Over much of his career he was recognized for his publications on plants poisonous to livestock. It is interesting to note that before 1920 his poisonous plant bulletins were being translated into Spanish. Perhaps his most famous and certainly most controversial publication was Nevada Bulletin 159, "Bronco Grass (Bromus tectorum) on Nevada Ranges," published in 1942 and coauthored with M. A. Shipley and M. R. Miller. The cover illustration for this bulletin featured a bunch of Hereford cows and calves near a water trough. The cows and calves appeared in good condition for August 1 on a range where cheatgrass was the only source of forage. In the Bronco Grass bulletin, the author opened with the statement,

\section{Bronco grass (sic Bromus tectorum) has become a permanent source of feed on many of our most important rangelands and it will necessarily have to be taken into consideration in the determination of seasonal use and in making grazing capacity estimates.}

More than a half century after Fleming posed his questions about grazing cheatgrass, the controversy continues. The profession of range management has been deeply involved in an imitation of the Roman Emperor Nero, but in this case they "fiddle" while the ranges of the Intermountain Area of Western North America burn.

Let us examine each of C. E. Fleming's contentions concerning the status of cheatgrass as a forage species in light of what has happened during the last half of the 20th century to Nevada rangelands. Hindsight is a wonderful procedure that allows one to be pretentious, so we evaluate the Fleming contentions in terms of their foresight.

\section{Do Annual Grasses Indicate Overgrazing?}

To interpret this question, you have to consider both time and the dominance of annual grasses in relation to native perennial grasses. By the time Fleming wrote his contentious article, part of this issue was already answered. R. F. Daubenmire published in his classic paper "Plant Succession Due to Overgrazing in the Agropyron Bunchgrass Prairie of Southeastern Washington," strong evidence that cheatgrass could invade native perennial grass communities that never had been grazed and were in excellent ecological condition. Therefore, this contention depends on the relative dominance of cheatgrass. Abundance of native perennial grasses and little cheatgrass does not mean the site is in poor range condition nor is the site improperly grazed. Conversely, complete cheatgrass dominance with no native perennial

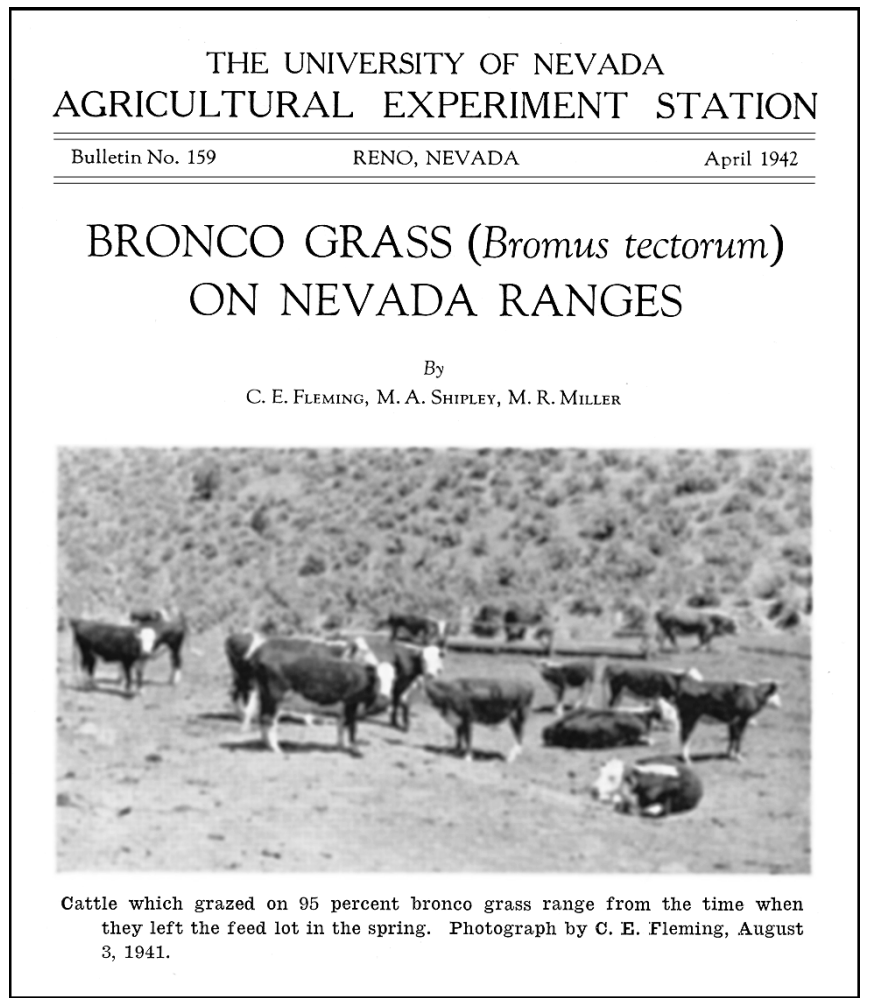

grasses as a result of past improper grazing does not mean the site is currently being improperly grazed. Leave enough litter to minimize accelerated erosion and to provide a seedbed suitable for cheatgrass germination and a conditional sustainable grazing resource results. You must be aware that sustainability of grazing cheatgrass stands is always at risk from invasion of the stands by plants that do not support grazing. This does not mean you cannot excessively graze cheatgrass. A. C. Hull, Jr., clearly showed in the 1940s it was possible to excessively graze cheatgrass to the point that there was no vegetation the next year except Russian thistle.

The point where range professionals in the public land management and academic sectors often erred, was to assume that grazing management that was proper for ranges dominated by native perennial grasses would automatically lead to a return of such grasses on sites almost exclusively occupied by cheatgrass. This applies across the board in grazing management practices, from reduced stocking numbers, delayed grazing until after seed ripe, to complete rest from grazing. Robin Tausch emphasized in his research on Great Basin plant communities the significance of thresholds in community dynamics. There is a point in the relative abundance of native perennial grasses and cheatgrass where native perennial grasses cannot ascend successionally across the cheatgrass threshold. This is especially significant with the application of rest-rotation grazing where cheatgrass benefits from deferred, no grazing until after seed ripe, and complete rest from grazing. 
Would the Annual Grasses Be Largely Absent From Nevada Ranges if There Had Been No Grazing?

Once cheatgrass was introduced, it was only a matter of time until virtually all plant communities in the pinyon/ juniper, big and dwarf sagebrush/bunchgrass, and salt desert rangelands of Nevada were invaded by the species. This was an inevitable conclusion, even in the absence of prior excessive grazing by domestic livestock. The widespread occurrence of excessive, improperly timed, and repeated grazing on Nevada rangelands heightened the rate of dispersal and greatly enhanced the post-dispersal dominance of cheatgrass. It is very important to make this distinction, because otherwise it leads to the false assumption that removing grazing by domestic livestock would automatically mean the disappearance of cheatgrass.

Once cheatgrass becomes established on a site, eventually it will cross a threshold where the abundance of the herbage of this annual will increase the chance of ignition and the rate of spread of wildfires. This sets into motion successional dynamics that lead to a reduction in the length of the interval between the reoccurrence of wildfires, which assures cheatgrass dominance. A parallel dynamic is set in motion where increased cheatgrass abundance progressively depletes soil moisture to the point where seedlings of native perennials cannot be recruited to the community. This dynamic was illustrated by Robertson and Pearse in their landmark paper "Artificial Reseeding And The Closed Community," published in 1945.

\section{Should the Carrying Capacity of a Predominantly Annual Range Be Based Upon the Perennials?}

In our recent experience, most new graduates of natural resource or biology curriculums are certain that "cows do not eat cheatgrass." In range management literature, cheatgrass as a grazing resource is roundly damned as a forage because of 1) a lack of digestible protein, 2) a short green feed period, 3) mature seeds that are extremely injurious to livestock, 4) herbage production that is extremely variable among years, 5) being such an extreme fire hazard that it cannot be counted on as a forage, and 6) not being eaten by domestic livestock once it is mature.

C. E. Fleming addressed many of these issues in the 1930s and 1940s. Cows and sheep prefer cheatgrass in the spring. Cheatgrass does not provide abundant forage in the very early spring unless there is significant fall germination. A mixture of dry cheatgrass from the previous growing season and green cheatgrass in the spring makes a highly desirable spring forage. The protein content of cheatgrass is similar to (or even higher than) native perennial grasses at the same stages of maturity. Native perennial grasses mature 2 to 6 weeks later in the summer than cheatgrass, depending on the perennial grass species, the site, and the periodicity of moisture events in a given year.
Once the native perennials are mature, they also provide a protein-deficient diet for cattle and sheep.

Livestock turn to shrubs as a source of protein in the late summer and early fall, no matter if it is a cheatgrass or perennial grass range. This is a point often missed in discussions of the consequences of repeated wildfires fueled by cheatgrass. Shrubs are eliminated by such a fire pattern and with their loss, the late summer, fall, and (for mule deer) winter digestible protein sources are lost.

The argument that cheatgrass cannot be a grazing resource because it is such a fire hazard has a basic flaw. It is a fire hazard when mature and dry. It is not a fire hazard when green and a preferred forage species. With the proper timing and intensity of grazing, there is virtually no cheatgrass herbage to burn after maturity. Yes, the abundant herbage of cheatgrass is an extreme fire hazard. Is this a reason for not grazing for fuel reduction? Another related aspect of spring grazing was first reported by Jackman and Platt in the 1940s for eastern Oregon. Properly timed grazing of cheatgrass in the spring increases the harvestable forage from the species through stimulation of tillering. This means that grazing management to reduce cheatgrass as a fuel for wildfires has to include late spring grazing in years with enough soil moisture for abundant tiller growth.

Frosty Tipton, a rancher at Winnemucca, Nevada, made the observation that the form of cheatgrass that invaded the salt desert ranges of Nevada in the last quarter of the 20th century tends to hold mature seeds in the seedheads rather than immediately dispersing them, which is the case with the traditional cheatgrass of sagebrush rangelands. Frosty observed cows turned out on winter ranges licking these dry seeds from the cheatgrass plants. Indian ricegrass has a form of seeds that do not dehisce from the seedheads and cows on salt desert ranges consistently favor consuming these inflorescence. Cows on salt desert winter ranges lick the seeds of chenopod shrubs from the soil surface that are too spiny to graze in the fall. This well-known behavior on arid ranges illustrates a deliberate act of seeking high-protein content seeds when protein is deficient in available grass herbage. Yes, the seeds of cheatgrass with their awn and sharply pointed tip of the caryopsis can be injurious to the eyes and mouths of grazing animals, and such injuries can lead to secondary infections. However, the danger of grazing mature cheatgrass is blown well out of proportion to the frequency of such injuries. The seeds of cheatgrass plants found in sagebrush environments dehisce so rapidly at maturity that the period of potential injury is transitory.

Fleming and his associates never directly addressed the issue of variability among years in the herbage production of cheatgrass as a detriment to grazing cheatgrass. This is the most significant issue facing livestock managers on cheatgrass ranges. B. L. Kay kept cheatgrass production figures for more than 30 years on the Likely Table in northeastern California. He determined there were more years below average than the average herbage production. This is 
because the high production years are so extreme (El Niño precipitation) in forage production. The primary livestock production system in Nevada and the entire Intermountain Area is cow-calf operations. Obviously, it is hard to instantaneously increase livestock numbers with such a system vs buying stocker cattle annually. It is not only the amount of precipitation received, but also the periodicity of these moisture events that determines the herbage production of cheatgrass. If you have to wait until May 1 to be sure you are going to have a banner cheatgrass production year, it is a little late to change cow and calf numbers. The naysayers for grazing cheatgrass have for 75 years used the variation among years in herbage production as a primary reason for not giving the annual grass any credit in forage production to determine stocking rates. They have smugly pointed out that in contrast to cheatgrass, in very dry years there is some production by native perennial grasses. If the native perennial grasses only have $10 \%$ of average forage production in very dry years and the same number of livestock are permitted to graze, perhaps some forage production in dry years has a bearing in the demise of the native perennials. This is in contrast to cheatgrass, which can sit out extreme droughts as viable, dormant seeds in seedbanks. This is especially true if cheatgrass constitutes $90 \%$ of the harvestable forage on good years.

Why do intelligent, dedicated individuals in public land management agencies and academia refuse to recognize cheatgrass as a major forage species? Cheatgrass is an invasive, exotic species that is an affront to classical Clementsian plant community ecology. This ecological theory was "range science" for much of the 20th century. It was applied by Arthur W. Sampson in his classic paper on assessing the quality of rangeland plant communities by comparing existing species composition with potential species composition. Manage grazing properly and succession will proceed to assemblages of plants in balance with the potential of the site. Cheatgrass refused to play by these rules and truncates succession to maintain its own dominance. To accept this as a fact of life on former big sagebrush/bunchgrass rangelands has been equated with accepting a lower standard of environmental quality. Charles Edgar Poulton thundered from the podium to generations of beginning range management students that, "If we drop the potential communities as our standards for range condition we will be like the Chinese and end up eating grass." Is it possible that far out in the deserts of Central Asia some poor nomad is right now removing his wok from a camel dug fire to have a square meal of cheatgrass?

To counter the assault on Clementsian ecological theory, range scientists have created a series of paper tigers. "Cows only eat cheatgrass when it is green" is a good example. With extreme reluctance, Federal land management agencies have agreed to assign some credit to cheatgrass as forage, but in most cases only when it is green. Winter ranges located in salt desert environments in the Great Basin are providing vast examples of landscapes where the bulk of the forage harvested by cattle is dry, mature cheatgrass. Except for areas of sand where Indian ricegrass is abundant or playa margins where basin wildrye dominates, many of the upland salt desert ranges lack native long-lived perennial grasses. Squirreltail and desert needlegrass are the only perennial grass in many of these communities. The spread of cheatgrass into these communities has increased herbaceous forage production by an order of magnitude. We observed cows and calves grazing on a well-managed winter range in Central Nevada in January 2006. It was a hauled-water operation with excellent distribution of watering points. The range consisted of a vast basin known as Big Bell Flat. The vegetation consisted of winterfat communities interspaced among fingers of black sagebrush. There was a discontinuous skiff of old snow on the ground. As soon as the sun took some of the chill off the very cold basin, the cows fed on winterfat browse. After about an hour they switched to grazing dry cheatgrass. Often the plants were pulled from the ground and were easily identified as the cows rolled up the plants to swallow. By 10:00 AM the cows had watered and were lying down chewing their cud. Most of their rumen fill apparently came from dry cheatgrass with winterfat providing digestible protein. The sad part of this grazing system is if the cheatgrass is not grazed the site will eventually burn and the winterfat will be lost. A cheatgrass forage source by its self on this site will not function because of protein deficiency.

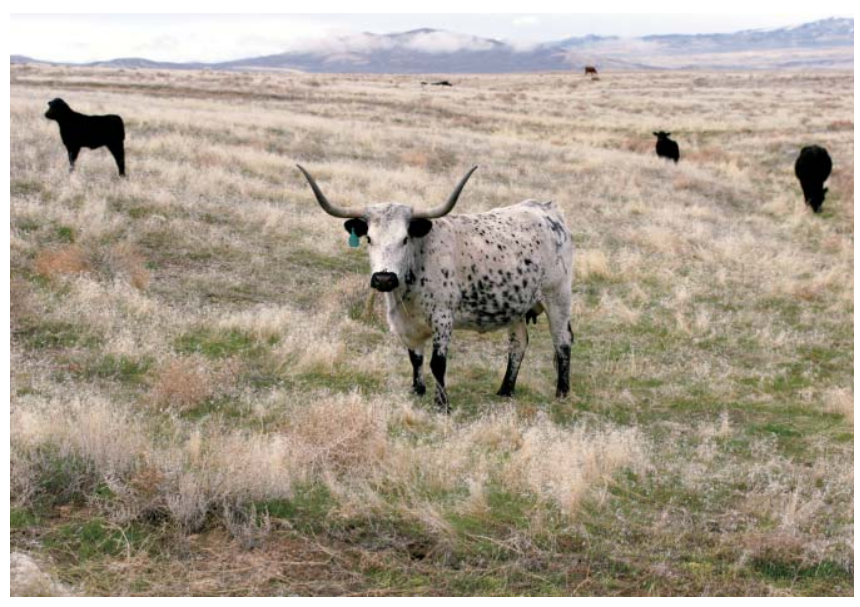

\section{Has Anyone a Practical Method by Which Annuals Can Be Replaced and Perennials Reestablished in a Density That Would Permit Saying the Range Has Been Brought Back to Its Pioneer Carrying Capacity?}

This question, asked by Fleming 50 years ago, is just as pertinent today. No one has been consistently successful with large-scale artificial seedings of native perennial grasses in the face of competition from cheatgrass. Dick Eckert, Raymond Evans, and B. L. Kay developed herbicide and 
tillage techniques that were successful in establishing crested wheatgrass seedings in the face of cheatgrass competition during the 1950s and 1960s. They were successful because they understood the nature and magnitude of competition from cheatgrass.

The first successful seeding of crested wheatgrass on Nevada rangelands was carried out by Joe Robertson in 1942 at Arthur in Elko County, Nevada. There is no mention of crested wheatgrass in the Nevada Agricultural Experiment Station annual reports during the 1940s. During the 1950s about a million acres of Nevada's degraded big sagebrush rangeland was seeded to crested wheatgrass. Much of the seeding was done to suppress the poisonous exotic species halogeton. Most of these succcessful seedings were carried out on degraded big sagebrush sites where competition from cheatgrass was minimal. Grazing management of cheatgrass on former perennial grass ranges in the Intermountain Area always comes back to the critical period in the very early spring that corresponds to the traditional date for turn-out of cattle on the ranges. This is when the native perennial grasses are most susceptible to damage by excessive grazing, and cheatgrass often lacks sufficient herbage production to contribute to the potential forage supply.

Native perennial grasses can be grazed in the spring, but not repeatedly every year, or excessively in any one year, and the grasses must be given a chance to recover while there is still soil moisture available. What the mid-20th century Intermountain Area livestock industry needed was a grass that tolerated grazing abuse in the early spring.

We had an answer to this problem in crested wheatgrass stands before this introduced perennial became a political liability. Martyn Caldwell clearly presented experimental evidence that crested wheatgrass had the potential to withstand moderate grazing in the very early spring and this resistance to grazing was totally lacking in bluebunch wheatgrass. You have to have a perennial grass that overlaps in growth requirements in order to biologically suppress cheatgrass. You have to have an alternative to grazing native perennial grasses in the very early spring. Crested wheatgrass is an ecological bandaid that fulfills both requirements. Read the evaluation of the Vale Project in southeastern Oregon that was prepared by Harold Heady and Jim Bartolome. The result of massive crested wheatgrass seedings on degraded big sagebrush/bunchgrass rangelands was a tremendous improvement in the ecological condition of the matrix of native ranges in which the much smaller acreage of crested wheatgrass seedings were located.

Seeding of crested wheatgrass virtually ceased on federally owned rangelands in the 1960s. After the fire storms of 1999 when 1.6 million acres of Nevada rangelands burned, approximately 42 million dollars was spent on restoration seedings. Much of these funds were spent on seeding native species with very limited or no success: seeding bluebunch wheatgrass in a 7-inch precipitation zone that on most years does not receive 5 inches of precipitation.

Modern researchers conducting experiments on cheatgrass suppression and seeding of native perennial grasses are astounded to find a host of other exotic species that appear to compete with their seedlings once cheatgrass is suppressed. In the early 1930s, R. L. Piemeisel pointed out that cheatgrass is part of a succession of exotic annual invasive species that have found a home on degraded big sagebrush rangelands. In Piemeisel's day this suite of exotics consisted of cheatgrass, Russian thistle, filaree, and tansy mustard. Now the list of exotics that occur in "cheatgrass" communities includes more than 40 exotic, invasive species, including biennial and perennial species.

\section{Is It Reasonable to Look at a Range, and If Annuals Predominate, Say That the Range Is Overstocked and Livestock Numbers Should Be Reduced?}

We have previously stressed that traditional grazing systems designed to favor native perennial grasses (such as providing a complete rest or defer grazing until after seed ripe) favor cheatgrass just as much as or more than they favor the perennial grasses. The critical time in cheatgrass grazing management is the period between the maturity of cheatgrass and the maturity of the native perennial grasses. Once the cheatgrass is mature, the still green native perennial grasses are selectively overgrazed by cattle. If the density of native perennials is low, even low levels of trespass grazing are sufficient to selectively over-utilize the native perennial grasses. Trespass grazing following a wildfire makes a mockery of the 2-year grazing exclusion policy, which already is a scientific mockery if the sites are dominated by cheatgrass.

If on the first of August you look across a former big sagebrush/bunchgrass landscape and it is an apparent solid stand of cheatgrass waving in the breeze, it is not a symptom of excessive grazing, but a symptom of gross, near-criminal negligence in management. Criminal, because management has permitted a fuel load that endangers human life and property as well as exposing an entire landscape to the continued cycle of cheatgrass-fueled wildfires and environmental degradation.

If ranchers and land managers are going to graze cheatgrass, they must have the flexibility to adjust existing grazing systems to fit the actual forage production on a given year without the expensive and time-consuming preparation of a new Environmental Assessment. Alternatively, the original assessment should be prepared to take into account both years when there is no cheatgrass and years when it is super abundant. Failing to break a rest-rotation grazing system to completely rest a unit with a predominance of native perennial grasses on a year when a cheatgrass-dominated pasture has sufficient forage production to sustain the livestock is poor management. Including a crested wheatgrass seeding in a rest-rotation grazing system where the other pastures 
are native perennial grass is the height of ridiculous. Turning out livestock on the crested wheatgrass pasture in the spring and then moving them to native range that contains some cheatgrass makes good ecological sense. Perhaps, returning to the crested wheatgrass seeding during the mid-summer period between the maturity of cheatgrass and the maturity of native perennial grasses is an option that should be evaluated.

\section{What Would C. E. Fleming Say About Nevada Rangelands Today?}

It is safe to say Fleming would be appalled. Appalled because the questions he asked in 1946 are still in the debate-no action stage. Appalled because the scale and magnitude of the conversion of big and low sagebrush and salt desert plant communities from native species to exotic annual dominance is so overwhelming. In the mid-1960s, the brilliant and flamboyant plant physiologist-ecologist Fritz Went stated that the problem with cheatgrass dominance of Nevada rangelands was that the communities are so open to invasion. At the time of this statement, Joe Robertson had already shown through analysis in field experiments that cheatgrass closed communities to the recruitment of seedlings of perennial species.

Fritz Went envisioned that other exotic annual species could successfully invade cheatgrass communities. Bur buttercup, medusahead, a second species of Russian thistle, numerous species of mustard, annual kochia, annual wheatgrass, and halogeton have shown the validity of Went's prediction. He carried it a step farther by predicting that cheatgrass, for all its landscape-level dominance, was a transitory issue and its replacement species would make cheatgrass appear as a highly desirable forage species. The question for 21 st century range scientists, managers, and any citizen concerned with environmental quality, is how we manage cheatgrass-dominated ranges to maintain cheatgrass dominance if society is not willing to spend the necessary funds for research and development and implementation to convert the ranges back to a perennial grasses capable of suppressing exotic annuals.

\section{Additional Reading on Early History of Cheatgrass}

Daubenmire, R. 1940. Plant succession due to overgrazing in the Agropyron bunchgrass prairie of southeastern Washington. Ecology 21:55-64.

Harris, G. H. 1967. Some competitive relationships between Agropyron spicatum and Bromus tectorum. Ecological Monographs 37:89-111.

Hironaka, M., and E. W. Tisdale. 1963. Secondary succession in annual vegetation in southern Idaho. Ecology 44:810-812. (Extends the research of Piemeisel, see below)
Hull, A. C. 1944. Regrassing southern Idaho rangelands. Moscow, ID: University of Idaho, Extension Bulletin 146.

Hull, A. C., And J. F. Pechanec. 1947. Cheatgrass-a challenge to range research. Journal of Forestry 45:555-564. (We wonder if the authors had any idea how much of a challenge they were introducing.)

Piemeisel, R. L. 1951. Causes affecting change and rate of change in a vegetation of annuals in Idaho. Ecology 32:53-72. (Published after his retirement, this is a summary of work completed during the 1930s.)

Platt, K., and E. R. Jackman. 1946. The cheatgrass problem in Oregon. Corvallis, OR: Oregon State College, Extension Bulletin 668. (Very hard to find a copy, but this is one of the best comprehensive discussions ever published. It also abounds with cheatgrass folk wit.)

Robertson, J. R., and C. K. Pearse. 1945. Range seeding and the closed community. Northwest Science 19:58-66. (Origin of the closed community concept.)

Stewart, G., And A. C. Hull. 1949. Cheatgrass (Bromus tectorum L.): an ecological intruder in southern Idaho. Ecology 30:58-74. (Besides being an early paper concerning cheatgrass, the title is a brilliant description of the problem.)

Appendix: Common and scientific names of plants mentioned

\begin{tabular}{|l|l|}
\hline annual wheatgrass & Eremopyrum triticeum \\
\hline big sagebrush & Artemisia tridentata \\
\hline blue mustard & Chorispora tenella \\
\hline bur buttercup & Ranunculus testiculatus \\
\hline cheatgrass & Bromus tectorum \\
\hline desert alyssum & Alyssum desertorum \\
\hline filaree & Erodium cicutarium \\
\hline halogeton & Halogeton glomeratus \\
\hline prickly lettuce & Lactua serriola \\
\hline Russian thistle & Salsola targus \\
\hline sagebrush & Artemisia sp. \\
\hline shield cress & Lepidium perfolatum \\
\hline tansy mustard (exotic) & Descurainia sophia \\
\hline tansy mustard (native) & Descurainia pinnata \\
\hline
\end{tabular}

Authors are Rangeland Scientists, USDA Agricultural Research Service, 920 Valley Road, Reno, NV 89512, jayoung@scs.unr.edu (Young) and charlie@scsr.nevada.edu (Clements). 